\title{
Pension Reform in Germany and Austria: System Change vs. Quantitative Retrenchment
}

\author{
MARIUS R. BUSEMEYER \\ University of Heidelberg, Heidelberg, Germany
}

\begin{abstract}
This article first outlines the differences in outcome of pension reform in Germany and Austria. The 2001 German pension reform cut benefits very little, but it started a system changing transformation process by strengthening the second (occupational pensions) and third pillar (private pensions). The 2003 Austrian pension reform, pushed through against major opposition from the labour unions, contains very few elements of policy innovation, but benefits have been cut back much more significantly than in the German case. The paper explains the difference in outcomes (system change in Germany, retrenchment in Austria) by looking at the structure of political institutions. The federal government in Austria is much less constrained by formal veto players than the German government, which had to engage in extensive coalition-building to get the pension bill through the second chamber of parliament. Therefore the influence of informal veto players (mainly unions) was much higher in Germany. The impact on the reform outcome was the positive discrimination of occupational pensions and less severe cuts in the benefit levels. The concluding thesis is that for successful and long-term sustainable welfare state reform, a small number of formal veto players is a valuable resource. A large number of formal veto players is an obstacle to retrenchment reforms, although it might encourage policy innovation, because political actors will look for other policy venues to increase their leverage.
\end{abstract}

\section{The Puzzle: Research Question and Hypotheses}

What impact does the number and power of veto players have on the character of pension retrenchment reform? This article tries to answer this question by comparing recent pension reforms in Germany and Austria. Both reforms aimed at reducing the fiscal burden of pension spending. But, although the goal of welfare state retrenchment played a prominent role in both cases, the character of the two reforms was very different. In the German case, we observe limited quantitative retrenchment, but considerable changes in the dynamics of the pension system, which could affect

Correspondence Address: marius_busemeyer@ksg05.harvard.edu 
spending in the long run. In contrast, we observe significant quantitative retrenchment in Austria, but no significant system changes. This article aims at explaining this puzzle.

The main hypothesis is that the number and power of veto players shapes the strategies of political actors and impacts on reform outcomes. Veto institutions therefore do not 'cause' reforms, but they affect the institutional environment of political actors. A high number of veto players increases the need for the mobilisation of consensus reserves. The government as agendasetter has to build a broader reform coalition in order to be able to get reform legislation passed and implemented. The building of a broad coalition becomes even less feasible if the actors occupying veto institutions have a competitive interaction orientation as a result of increased politicisation of veto institutions (e.g. the German Bundesrat).

More specifically, the number and power of veto players has an impact on the feasibility of different policy options. First, as is well known from the theoretical predictions of Tsebelis (2002), a large number of veto players, low policy congruence between players and a high internal cohesion leads to smaller policy changes, that is, the predominance of incrementalist legislation over wide-ranging reforms. Second, the existence of powerful veto players encourages the use of low visibility policies. These are policies that are designed in a technical manner in order to obfuscate the long-term implications of these policies. In addition, the ramifications of low-visibility policies are often not obvious to the non-expert.

Therefore, it is hypothesised that quantitative retrenchment is less feasible in the presence of an extensive veto structure, because quantitative cut-backs are highly visible and policy changes are deemed to be non-incremental. In an institutional environment that is characterised by a high number of veto players, the policy option of system change becomes more attractive: There is a higher potential for low visibility policies as even incremental changes in the dynamics of the system can lead to significant policy changes in the long term. A government might be interested in altering the dynamics of the system in order to shape the future political landscape and leave a strong policy inheritance for its successor.

However, countries with a low number of veto players (i.e. unitarian, nonfederalist countries) have a broader range of policy options. In theory, they can choose between quantitative retrenchment and system change. Quantitative cut-backs will on average entail a higher price in political capital in the short term than low-visibility policies. But in the medium to long term, they might produce higher political benefits when the reform produces positive returns. Furthermore, if the existing system is buttressed by strong entrenched interests and if sunk costs are high, the government will prefer to maintain the existing institutions.

Concerning political strategies, it is to be expected that in countries with a high number of veto points, the government as agenda-setter will have to rely on varying coalitions. What is more, the government may have to 
engage in building different coalitions during the legislative process. The interests of members of the reform coalition will have an impact on the outcomes as can be seen from the impact of union participation in the German reform coalition on the reform outcome. In contrast to countries with a weak veto structure, unilateral strategies of pushing through with reforms are less feasible. A confrontational policy-making style will soon result in gridlock and stagnation. In countries with a low number of veto players, unilateral strategies are more feasible although they entail high political costs here, too. Reform outcomes, however, are expected to be less shaped by special interest coalitions. Therefore, there is a higher chance that reform outcomes will be more effective at dealing with policy problems (i.e. rising pension costs because of ageing).

A comparison of recent pension reform in Germany and Austria offers a very good opportunity to evaluate these hypotheses. Germany and Austria are countries with many similarities. They share a common historical heritage and a similar political culture. With the rise of the Greens in the 1980s and the recent decision of the Österreichische Volkspartei (ÖVP) to include the Freiheitliche Partei Österreichs (FPÖ) in government, the Austrian party system has converged towards its German counterpart with its two opposing blocks, each containing one of the major parties (the Volksparteien) and a smaller party. This bipolarisation of the party system went hand-in-hand with increasing polarisation and a conflictual style of policy-making, which for Austria is a more recent development than for Germany. Furthermore, both countries have been ruled either by a social democratic or a Christian democratic government, in coalition or alone, since 1949. For both party families, the building of a comprehensive welfare state was one of the most important policy goals after the Second World War. Theories that try to explain variations in outcome with the differences in the dynamics of party competition and are sceptical about the role of institutional veto points (Kitschelt 2001) cannot explain the variations in the character of pension provision. In both countries, the parties in government had to face opposition from the right (from the Christlich Demokratische Union/Christlich Soziale Union (CDU/CSU) opposition in Germany; parts of the FPÖ in Austria) and from the left (from the Partei des Demokratischen Sozialismus (PDS) in Germany; from the Sozialdemokratische Partei Österreichs (SPÖ) and the Greens in Austria). Furthermore, although social and Christian democratic parties have quite diverging views on certain aspects of social policy (education, child care), both favour extensive pension spending. So, while, in general, updated actor-centred approaches (Scharpf 2000a; 2000b) have become something close to a standard in explaining policy differences between countries, nevertheless this specific case of pension reform in two countries with very similar characteristics offers an exceptionally good opportunity to study the impact of veto institutions on policy outcomes, holding actorrelated variables 'constant'. This approach may not be able to explain all 
the differences in policy outcomes, but it can significantly contribute to a better understanding of the dynamics of veto institutions and pension reform.

Apart from similarities in the configuration of the party system, both countries devote a very significant share of their gross domestic product (GDP) to the maintenance of the social state: in Austria, public social expenditure amounted to 26.0 per cent of GDP in 2001, whereas Germany spent as much as 27.4 per cent of its GDP on social policy (according to the Organization for Economic Co-operation and Development (OECD) Social Expenditure Database). Furthermore, the nature of the welfare state in both countries is very similar: both belong to Esping-Andersen's world of the conservative welfare states (EspingAndersen 1990), which characteristically spend more on compensatory social transfer payments and less on social investment policies, such as childcare facilities or nursing homes, have a tendency to develop insideroutsider cleavages (the unemployed vs. the employed), and a strong preference for social insurance solutions instead of universal public Beveridge-type social policy schemes.

For both countries the pressure to reform their welfare states has grown in recent years. Demographic change (the increasing proportion of elderly people), pressures for fiscal conservatism from the EU level (the EMU Stability and Growth Pact), and the imperatives of international competition for mobile capital put a strain on public pension schemes to hold spending at bay. Here again differences in policy motivation of governing parties (i.e. the social democrats may still be more reluctant to cut back welfare spending) are trumped by the pressures for reform that originate in the socioeconomic environment.

\section{Policy Outcomes of Pension Reform in Germany and Austria}

To cope with the pressure of the growing problem, both countries have previously engaged in restrictive pension reforms with mixed results. In Germany, the 1992 pension reform (passed in 1989) was a first step down the path of retrenchment, to be continued by the 1999 pension reform (passed in 1997), which was later suspended by the Schröder government. In Austria, the consolidation packages of the 1990s, which were enacted in preparation for membership in the EU, already contained some measures to restrict spending on pensions. Another restrictive reform followed in 1997, still under the direction of a Grand Coalition, and the incoming Schüssel government passed another pension reform in 2000 that raised the entry age to Austria's system of early retirement (The Economist, 'Taking a Risk', 19 April 2003). The two reforms that are the subject of this analysis are, however, the most ambitious projects of pension reform so far, namely the 2001 pension reform in Germany and the 2003 reform in Austria. 


\section{The 2001 German Pension Reform}

At the end of the 1990s, 80 per cent of German pension payments came from the pay-as-you-go-financed public pillar, whereas 10 per cent each came from the rather underdeveloped second (occupational pensions) and third pillar (individual private pensions) (Schmähl 2004: 159-60). The main goal of the pension reform was to disburden the first, public pillar in order to reduce the amount of grant that the federal government pays into the insurance system to compensate for 'non-insurance' benefits of the system and to reduce the relatively high non-wage labour costs by decreasing the contribution rates. The pension reform tries to achieve this goal by granting tax subsidies and tax exemptions as well as by supporting the expansion of existing occupational pension schemes and the development of new instruments in occupational pensions. There are, however, slight differences between the second and the third pillars. First, an employee can receive subsidies (or tax exemptions, whichever is more beneficial) if the employee invests a certain share of gross income in certified investment products (the so-called 'Riester-Rente', named after Walter Riester, the then Minister for Labour and Social Affairs). ${ }^{1}$ Although it is possible to interrupt payments for the Riester-Rente (e.g. because of unemployment), there will be no further accumulation of pension entitlements during these times as the system is fully capitalised. This stands in contrast to the public pension system, where raising children or periods of unemployment still establish entitlements to pension benefits (Schmähl 2004: 185). The share of gross wages for which subsidies are granted rises from 1 per cent in 2002 to 4 per cent in 2008. The magnitude of the subsidies is considerable: For low income families, public subsidies amount to more than 50 per cent of the total amount of subsidised private savings. ${ }^{2}$

Second, the reform is expected to revive the occupational pension pillar. In certain rather subtle ways, occupational pensions are favoured against personal savings. This is a good example of low visibility policies. Furthermore, it is important to note that the reforms in occupational pensions were originally not part of the reform, but were included on the demand of the unions (Schmähl 2004: 184, see below).

In conjunction with the expansion of the second and third pillars, the reform aims at reducing the role of the public sector by reducing benefits. One of the main goals of the reform is to keep the level of the contribution rate below 20 per cent in 2020 and below 22 per cent in 2030 (VDR 2001: 3). This aim is to be achieved through using a new formula to calculate pension adjustments. Previously, pensions were adjusted according to the development of net wages. This created the adverse effect that pension expenditure rose when the government tried to decrease the tax burden on gross wages (because net wages rose faster). The new formula for adjustment is the socalled 'modified gross wage adjustment'. Pensions are adjusted in line with the development of gross wages, from which the contributions to the public 
pension system as well as the assumed share of voluntary investment in private pensions are deducted (VDR 2001: 5). A rise in the contribution rates automatically leads to a slower increase of pension benefits. The most important point is the inclusion of the share of the voluntary investment in private pension in the formula to calculate the modified gross wage. This figure is a political construct and therefore to some extent 'fictitious' (Schmähl 2004: 175). The government can tinker with this fictitious rate of private savings to further reduce the benefit level, again a prime example of low visibility policies.

The changes in the pension formula are expected to lead to a decrease in the level of the standard pension ${ }^{3}$ from 70 per cent to 67 per cent of average net earnings. There is some dispute in the literature about the exact magnitude of expected benefit reductions. Originally, the government had aimed at a reduction of the net pension level to 64 per cent (which was exactly the level the $1999 \mathrm{Kohl}$ pension reform had achieved already). The final bill, however, contains a guarantee that the federal government must not let the net pension level fall below 67 per cent (VDR 2001: 5). According to Schmähl (2004: 176, n.46), the government changed the definition of net earnings by counting the voluntary private savings as a mandatory levy. Thereby, a lower absolute level of pension leads to a higher percentage in relation to average net earnings. The literature is split on the issue but does not seem to consider this to be a problem. ${ }^{4}$

Another, but for our purposes less important, element of the pension reform was the introduction of a means-tested transfer payment in the case of insufficient income for persons aged 65 and above, which is similar to social assistance with the difference that children do not have to pay back the whole sum or part of it (if their income does not exceed $€ 100,000$ per year) (Schmähl 2004: 162). This is the less ambitious version of proposals of a universal means-tested basic income scheme for the elderly which had been floating around during the election campaign of 1998 and shortly thereafter.

The expectations of the effects of the 2001 pension reform diverge greatly. Some speak of a 'paradigm shift' (Schmähl 2004) and 'the most fundamental changes in pension policies since 1957' (Lamping and Rüb 2002: 5), whereas others (Kohl 2001; Seeleib-Kaiser 2003) stress the continuity of welfare state reforms and the limited magnitude of the changes. It is important to note, however, that the ones that speak of 'system change' (Lamping and Rüb 2002: 8) put their emphasis on the more innovative elements of the reform (the strengthening of the second and third pillars), from which they expect a major transformation of the German system in the long run. They also emphasise the changes in the underlying logic of the pension system: The transformation from a defined benefit system to a defined contribution system (where the level of the contribution rate is the single most important variable) goes hand-in-hand with the abandonment of maintaining living standards in old age through public pensions alone and with delegating this 
task jointly to the public and private pension systems. ${ }^{5}$ This confirms a trend towards 'expenditure-oriented revenue policy' (Schmäh1 2004: 164) that puts the distribution of benefits under the condition of availability of resources. This trend can be traced back to the 1992 reform.

However, Kohl (2001) stresses the limited magnitude of benefit reductions by stating that the net pension level has been varying between 68 per cent and 72 per cent since the 1970s (ibid.: 621). In the 2001 reform, the net pension level is planned to decrease to 67 per cent only in 2030. Rightly, Kohl considers it to be "hardly comprehensible, when some critics see an abandonment of the goal of securing living standards in the planned reduction of the net pension level by 2 per cent' (ibid., own translation). Moreover, the impact of the pension reform on contribution rates is also very limited: the estimated contribution rate for 2010 or 2020 is only 1 per cent, for 2030 only 1.6 per cent lower than the contribution rate without the reform. The employers' share in contribution rates is expected to be 11 per cent instead of 12 per cent in 2030 (Schmähl 2004: 181). Another indication of the limited magnitude of the reform in the spendings dimension is the latest effort by the government to keep spending under control. By implementing short-term measures (such as decreasing the required amount of capital reserves from 50 per cent to 20 per cent of monthly expenditure, suspending pension adjustments, and introducing a 'sustainability factor' that decreases benefits), the government has managed to stabilise contribution rates at 19.5 per cent. Without these measures, the contribution rate would rise to 20.5 per cent (Bundesregierung 2003: 69) in the coming years, a level that was planned to be reached only in 2020 .

In conclusion, the main characteristics of the 2001 pension reform are found to be: very limited reductions in spending, but a considerable recalibration of the public-private mix in the system that points in the direction of change towards a system where the private sector plays a larger role than before.

\section{The 2003 Austrian Pension Reform}

The Austrian pension reform is much more straightforward than the German reform. The main elements of the pension reform are (EIU Country Report Austria, August 2003: 17-18):

- Phasing out early retirement. From July 2004 the early retirement age will be raised until it reaches the normal retirement age ( 65 for men, 60 for women). This process will be completed by 2017 (which was 2009 in the early stages of the law). Early retirement in Austria as in Germany has been a very popular policy instrument to reduce labour supply and unemployment in the 1980s (Hemerijck et al. 2000).

- Encouraging late retirement. Individuals employed longer than the normal retirement age receive bonuses of 4.2 per cent a year, employees 
who opt for early retirement will receive 4.2 per cent less a year (compared with 3.75 per cent before the reform).

- Rise in the base contribution period for the calculation of benefits from the best 15 to 40 years. Because the average income of an employee over a period of 40 years is lower than in the best 15 years of a career, this will lead to a significant reduction in benefits. Maximum losses to benefits will be capped at 3.5 per cent until 2007,7 per cent until 2015 , and 10 per cent thereafter (ibid.: 18) for those aged over 35.

- Rise in contribution period for full pension from 40 to 45 years.

- Establishment of a hardship fund (which was included because of pressure from the FPÖ) for workers with pensions lower than $€ 1,000$ per month and who have paid into the system for at least 30 years.

- Instead of 18 months, the first 24 months will be counted to establish pension claims in the case of raising children. ${ }^{6}$ This is one of the few expansionary measures of the reform. The full 24 months will only be counted as claims-establishing if the person was eligible to receive family allowance, which encourages women to stay at home to raise children instead of working.

In contrast to the German reform, the magnitude of expected benefit reductions is significantly larger, although one has to emphasise that the reductions start from a higher level: in Austria, the standard replacement rate is 80 per cent of incomes compared to 70 per cent in Germany. ${ }^{7}$ Hence, even though the Austrian pension reform entailed significant quantitative retrenchment, the benefit levels after the reform are still comparable to the relatively generous levels in Germany. The Austrian pension reform further aims at eliminating inefficiencies in the system (early retirement) as well as a general reduction of public expenditure through expenditure cuts, but it does not follow the German example by expanding private and occupational pensions. Herbert Haupt, the head of the FPÖ and Minister for Social Affairs in the Schüssel government, and the FPÖ have declared the expansion of the second and the third pillars as a long-term policy goal, ${ }^{8}$ but so far there has not been a convincing political push. ${ }^{\text {? }}$

Our leading research question is therefore how we can explain the difference in outcomes in pension reforms in Austria and Germany. The German case is an example of limited and insufficient benefit reductions (OECD 2002: 14), accompanied by a gradual transformation of the system and a realignment in the public-private mix. The Austrian case is an example of decisive benefit reductions which seem to make the system fiscally sustainable in the long term (OECD 2003: 13). But a transformation and incorporation of innovative elements in the pension system has so far not happened.

If we adapt the perspective of Esping-Andersen's (1990) 'worlds of welfare' typology, we can see that reform policies in Germany constitute a gradual system change, whereas the Austrian case is an example of system 
retrenchment. The partial adoption of private sector elements in the provision of old age security in Germany is a move away from the ideal-type conservative welfare state towards the liberal world. The responsibility for securing the lifestyle and societal position of the employee, being one of the most discernible elements of the conservative welfare state type, is no longer in the state's hands only. Instead, there has been a readjustment in the public-private mix, with the individual carrying more responsibility. In contrast, in Austria, we cannot detect a system-changing move away from the conservative model. However, we find rather strong retrenchment within the structural and institutional limits of the conservative welfare state. Therefore, Germany and Austria have reacted differently to the challenges of ageing and economic internationalisation: system change or retrenchment can both be seen as attempts to cope with these challenges. To judge how effective these responses are is beyond the scope of this article. Instead, we focus on answering the question how the different paths of system adaptation came about.

\section{Political Strategies and Veto Players}

This section argues that the structure and nature of political institutions had a major impact on the availability of different political strategies. But apart from the institutional structure, perceptions and interaction orientations of actors played a major role too.

To begin with, some clarification of concepts and terms is necessary. The idea of veto players (Tsebelis 2002) and veto points (Immergut 1992) play a central role in the following argument. Veto players and veto points are two distinct, albeit related, concepts. Yet in the literature a clear separation of these concepts is often lacking. The distinction between institutions and politics is helpful in drawing the separating line. Here, veto points are conceptually defined as characteristics of the institutional structure that lies beneath politics. Therefore, veto points can be seen as institutions themselves. In fact, veto points can be distinguished from other institutions by one certain characteristic: their veto power, meaning that they are enabling access-points for political actors to mount mainly passive, preventative, less actively policy-shaping effective resistance against policies mandated by the central government. Yet veto points by themselves are not actors, only enabling institutions. In contrast, veto players are political actors, who not only have the ability, but also the political will and motivation to exercise effective resistance against central governmental policies. Once again, the distinction between veto points and veto players, who successfully capture veto points, and 'normal' political institutions and actors lies in the effectiveness of their actions in preventing governmental policies, that is the magnitude of their veto power.

Another distinction can be drawn between formal and informal veto points. Formal veto points - Tsebelis (2002: 19) institutional veto players - 
are mandated by the constitution. In contrast to Tsebelis and common veto player indices (Schmidt 2000: 353), we restrict veto points to institutions only, which constitute the country-specific constitutional veto structure (Czada 2003: 180). In contrast, informal veto points are constituted less by written law than through inherited institutions of the political decisionmaking process. The Austrian case shows that informal veto points granted to the social partners can be circumvented by the central government if, and only if, the government does not have to confront other powerful veto players, or, in other words, if the country does not have a comprehensive constitutional veto structure with many formal veto points.

\section{Austria: The Strategy of 'Pushing Through'}

In common veto player indices (Schmidt 2000: 352-53), Austria receives moderate scores, indicating that there are some counter-majoritarian institutions like federalism, a strong supreme court, and direct democracy instruments. Yet the Austrian federal government is not scored to be as constrained as for example the governments of the USA or Germany. Obinger (2001: 385) argues that most of these indices systematically overrate the veto potential that lies in the Austrian polity (cf. also Tálos 2002). In a first step, Obinger distinguishes between formal and informal veto players (Obinger 2001: 363). The power and competencies of formal veto players is normally laid down in the constitution or constitutional laws, whereas the power of informal veto players, such as the Austrian interest mediation system of social partnership (Sozialpartnerschaft), is not deduced from constitutional principles, but from their de facto standing in the political struggle.

First to be considered is the veto potential of formal veto players. Federalism in Austria, although fully-fledged, gives more competences to the federal level than to the states, especially in the policy area of social insurance policy (ibid.: 367-68). The Austrian federal system does not suffer from the problems of joint decision traps (Scharpf 1985) as much as the German system. The second chamber of parliament, the Bundesrat, is quite different from its German counterpart. Members of the Austrian Bundesrat are elected by the state diets, whereas in Germany they are delegates from the Länder governments, often prominent state governors and party leaders. In Austria, each state diet sends delegates according to the composition of the diet. In Germany, the government delegates are only from the governing parties. The German Länder governments have a mandate on the votes that have to be cast unanimously for each state. Second, the Austrian Bundesrat only has suspensive veto rights that can be overruled by the first chamber of parliament, the Nationalrat, by a simple majority (with a quorum of 50 per cent). Therefore, the formal veto power and also the political profile of the Austrian Bundesrat (being a member is merely a stepping-stone in the political career) are much lower than that of the German Bundesrat. In 
addition, Schüssel's government coalition had a comfortable majority of 39 out of 62 seats in the Bundesrat at the time the reform bill was passed. ${ }^{10}$

The president of Austria (the Bundespräsident) formally has major powers similar to the French president, but in constitutional practice he normally restrains himself to more representative functions. In the process of the pension reform, the president, Thomas Klestil, tried to get the parties and the social partners to negotiate with each other and to return to the Austrian practice of consociational decision-making (DPA, 8 May 2003). In the end, with the unions mobilising on the streets and the Schüssel government's mind set on pushing the reform through, his attempts were futile.

The Supreme Court and direct democracy did not play a major role in the reform process, so we focus now, secondly, on the informal veto players. The labour unions were strictly opposed to the reform bill. The unions managed to mobilise two major strikes: One on 6 May, which brought 500,000 people onto the streets, and an even bigger one (with over a million people striking) on 3 June (Der Standard, 4 June 2003: 1; 8 May 2003: 40). Although the strikes had less severe consequences for public life than feared, in a country like Austria, which maintains an extraordinary level of social peace, these had been the biggest strikes for over half a century (The New York Times, 'West Europe is Hard Hit by Strikes over Pensions', 4 June 2003: 9). In addition, member of the ÖVP fraction in parliament and head of the powerful Union of Public Employees, Fritz Neugebauer, and the president of the Economics Chamber and member of the ÖVP, Christoph Leitl, criticised the departure from decades of stability and Austria's system of consensus with the social partners (Deutsche Presse Agentur (DPA), 'VP Internal Conflict over Pensions Reform', 17 April 2003; 'Schuessel Accused of Hazarding Stability and Foreign Investment', 28 April 2003).

Although the government is obliged to listen to the statements of the social partners within the formal process of the Begutachtungsverfahren ${ }^{11}$ that is required before the introduction of each bill, the Schüssel government could and did in the end largely disregard the unions' protests. Even though the system of the Sozialpartnerschaft and consensual decision-making is deeply entrenched in the political culture of the country, the extraordinary powers of the first chamber of parliament and therefore also of the government that controls the majority in parliament can in principle decide freely on 'the extent to which it will allow these arrangements [of corporatism and consociationalism] to tie its hands' (Müller 2003: 222). The maintenance of corporatism and consociationalism is not based on constitutional requirements but 'on rational calculations on the part of the parliamentary majority' (ibid.: 246). Because the Schüssel government knew that the social partners, that is mainly but not only the unions, would be opposed to far-reaching reforms, it followed a political strategy of 'pushing through'. It was able to do so because it did not have to face powerful formal veto players and because the constitutionally prescribed structure of 
political institutions grants the majority in the Nationalrat far-reaching powers.

Yet amidst all the conflicts between the government and the unions, both sides were still willing to talk to each other. The government and the ÖGB held lengthy negotiations in late May. The unions managed to win a key concession on 23 May: benefit reductions would be cut off at a level of 10 per cent (DPA, 'Austria on Knife-Edge between Pensions Agreement and New Strikes', 25 May 2003). Moreover, after the bill was passed in parliament, Schüssel met together with the unions for new talks about further reforms in the pension system (i.e. the harmonisation of private and public pensions). Although the president of the ÖGB, Franz Verzetnitsch, was still opposed to the pension reform, he did not completely refuse any further negotiations with the government (DPA, 'Schuessel Offers Unions Further Talks on Pensions Reform', 13 June 2003). Both sides described the talks later as constructive (EIU Country Report Austria, August 2003: 18). The Austrian system of consensual policy-making seems to be able to withstand periods of conflictual policy-making without sacrificing the whole system altogether.

Schüssel's ambitious project of pension reform was, however, less endangered by the protesting unions than by opposition from within his own party and his coalition partner, the FPÖ. The protests (mentioned above) were from Neugebauer and Leitl, who are both ÖVP members. But the real spoiler in the project was the FPÖ. This contradicts the prediction of Obinger (2001: 379). In his view, the internal cohesion of the ÖVP is lower than that of the FPÖ, because the ÖVP consists of three covenants (Bünde), which represent agrarian, economic and employees' interests. Each of these Bünde becomes a party-internal veto player when decisions have to be made unanimously. Even when decisions are made by majority, it is politically not feasible to condemn one Bund, such as the employees' Bund, to a permanent minority position (ibid.: 380). Therefore, Obinger expects the ÖVP to have a lower internal cohesion than the FPÖ, which he believes to be under the autocratic rule of Jörg Haider. The example of the pension reform, however, demonstrates that Haider has adopted the role of a spoiler. This can be seen as a reaction to him losing grip on the party leadership, which he was forced to give up formally after the 2000 inauguration of the ÖVP/FPÖ government. During the reform process, Haider pushed for a public referendum on the reform and even made his party colleague Herbert Haupt, the Minister for Social Affairs, support this idea, although Haupt himself was responsible for the draft of the reform bill (The Economist, 19 April 2003). Later on, Haider argued for the setting up of a hardship fund that would alleviate the burden for low income pensioners and for a reduction of up to 15 per cent in politicians' pensions (DPA, 'Schuessel Presents Amended Pensions Law to Parliament', 4 June 2003). More importantly, Haider managed to get eight members of the FPÖ parliamentary fraction to revolt against the reform 
bill before the final decision in parliament. Schüssel had to engage in lengthy negotiations with Haupt and make some sacrifices (e.g. phasing out early retirement by 2017 instead of 2012). The bill passed the Nationalrat on 11 June and went on to the Bundesrat. Here again, nine of the ten FPÖ delegates (all from the Haider stronghold of Carinthia) refused to comply. They voted against a proposition by the ÖVP not to allow further amendments to the budgetary laws (which include the pension reform), but also against the SPÖ's proposition for an amendment. The result was a two-month delay in implementing the legislation (DPA, 'Schuessel Annoyed at Coalition Partner's Curious Voting Behaviour', 24 June 2003). In the end, the FPÖ's spoiler strategy prevented an even more far-reaching reform, although it did not seriously endanger Schüssel's strategy of 'pushing through'.

\section{Germany: The Strategy of 'Experimental Law-making'12}

The power of the federal government in Germany vis-á-vis the Länder and their representative institution on the federal level, the Bundesrat, is much more limited than in Austria. In the area of social policy and pension reform, the Bundesrat has absolute veto power, because the pension system is partly financed by general tax revenue, which is collected jointly by the federal, the state, and the local level for the most important tax sources (e.g. income tax). If there is no majority in the Bundesrat voting for a proposal, the bill fails. In principle, all major reforms that have fiscal consequences are consent laws, that is they require a supportive majority in the Bundesrat. The fact that members are delegates from the Länder governments and often important party politicians and state governors gives the German Bundesrat a highly visible political profile. In conjunction with its constitutionally prescribed veto powers, this further increases its veto potential. The Schröder government knew that for a major pension reform it would need a majority in the second parliamentary chamber.

Because members of the Bundesrat are not directly affiliated to the federal party leadership it always requires a significant political effort to organise the respective majorities. Before the spring of 1999 , there was a majority of delegates from states that were governed by the SPD or a coalition of the SPD with the Greens (the so-called ' $A$ Länder'). After the SPD lost the elections in Hesse, the majority in the Bundesrat was also lost. The Austrian strategy of 'pushing through' was therefore not feasible, because all efforts of unilateral strategy would probably fail in the Bundesrat.

Therefore, the government had to choose between two different strategies: One strategy can be named the 'Grand Coalition strategy'. The German system of political institutions encourages the building of formal or informal project-bound coalitions between the two major parties (the SPD and the CDU), when major reforms (constitutional amendments, reforms of the federalist system, changes in the tax and welfare state system) are to be 
achieved (Schmidt 1996a). Because of the long-term nature of decisions in pension policy, until the Kohl 1999 reform, all major pension reforms (1957, 1972, 1992) in the Federal Republic have been passed with the consent of the two big parties (Schmähl 2004: 155; Schmidt 1998). To achieve a consensus between the SPD and the CDU had been the dominant strategy for pension reform and the pursuit of this strategy is encouraged by the political institutions of the 'grand coalition state' (Schmidt 1996a).

In conceptual terms, the Grand Coalition strategy focuses on the partisan veto players, that occupy the formal veto points (here mainly the Bundesrat). Parties in government all represent veto players in Tsebelis' terms, because each one has to give its consent in order to enable the government as collective actor to make a decision. However, all parties in government share the common interest of keeping the government in power. This is not the case for the opposition party, whose interest lies in scrutinising the government and eventually contributing to its demise. Therefore, policy conflicts between the governing parties and the opposition parties in Germany are strongly influenced by the imperatives of political competition. Because Tsebelis' theory focuses on the policy position of actors only, it fails to recognise the impact of party competition. In the German case, the fierce competition between the two major parties prevented swift decision-making in the Bundesrat, although policy positions of the partisan actors were very close and the government made frequent concessions to the opposition.

A rising sharpness in the political competition and increasingly diverging majorities in the two parliamentary chambers have aggravated the business of pension politics. Since the beginning of the 1990s, the federal government could not effectively control a majority in the Bundesrat, ${ }^{13}$ which made the involvement of the major opposition party necessary for larger policy innovations. In addition, the consensus on policy reform has to reach beyond the realm of party politics into the corporatist system of interest intermediation, or the coalition between the two big parties has to be strong enough to withstand pressure from the interest groups, because the decentralised state structure establishes 'a wide variety of access points at the national, state and local level as also in the parapublic institutions' (Schmidt 1996a: 82) to interest groups.

As early as 1999, when the cornerstones of the pension reform were presented by Riester, the government tried to engage the CDU in consensus talks, but the CDU mobilised jointly with the unions against the pension reform and Eichel's consolidation plans. In the autumn of 1999, the government started another attempt at talks with the CDU. The CDU opposed Riester's proposal of mandatory private pensions and opted for a voluntary solution. Although the government eventually adopted this proposal, the CDU left the talks in the summer of 2000. With the introduction of the first draft of the bill in autumn 2000 (the Referentenentwurf) the government again tried to encourage talks with the CDU, 
which the CDU had left in October 2000. After the bill passed the Bundestag and went on to the Bundesrat, the government and the opposition were forced to negotiate by the procedural regulations of the law-making process. Opposition and government engaged in formal and informal negotiations in and outside the conference committee, whose function it is to find a common solution when the majorities in the chambers diverge. At the end, they did not reach a consensus and the government produced a so-called 'faked mediation result' (unechtes Vermittlungsergebnis) (Frankfurter Rundschau, 10 May 2001), a compromise proposal passed by the conference committee with the votes of the government coalition, which had a slight majority in the committee, against the votes of the opposition. By then the CDU leadership had already realised that it had lost the battle, because the Schröder government had managed to buy the consent of some Länder governments by specific concessions.

Why did the CDU continuously oppose the efforts of the government to draw it into a broad consensus, although the government made significant concessions, and why did the government desperately try to do so, although it knew that the CDU was not willing to cooperate? There are two answers to the first question. First, there is no rational incentive for the CDU to help the government pass a long-awaited reform if the policy preferences of the government are close to those of the opposition. If there had been major differences in policy, then participation in consensus talks would have meant an opportunity to influence the policy content of the reform. But the Schröder pension reform was in fact just an upgrade of the 1999 Kohl reform, which the SPD had suspended. The CDU did not want to grant the SPD the success of being able to implement a major reform when the SPD had refused to do so in 1997. Because there were no gains to be made by cooperation, the CDU tried to gain votes by opposing an unpopular reform. ${ }^{14}$ The upcoming elections in Rhineland-Palatinate and BadenWürttemberg on 25 March prolonged the stalemate in the conference committee. Second, the CDU was much too weak to be able to cooperate. In 1999, a major party finance scandal threw the party into the deepest crisis of its existence. The new party leader, Angela Merkel, had to work hard to stabilise her leadership position against the still powerful Kohl faction and her emerging adversary, Roland Koch from Hesse. Trying to push an unpopular compromise proposal with the SPD through the party boards would have meant the end of her political career. The fact that the internal party cohesion in the CDU was not very high later saved the pension reform, because Schröder was able to buy CDU-governed Länder out of the opposition front.

The second question was why the government continuously tried to make the CDU cooperate, although chances that it would do so were slim. First, the structure of political institutions makes it quasi-formally necessary to cooperate with the opposition. This is especially relevant for the later phase of the decision-making process, when the bill was stuck in the conference 
committee. Second, as pointed out above, the 'Grand Coalition strategy' had been the dominant strategy for pension reform since the beginnings of the Federal Republic. The government could expect a deeper reform if it had to take into account only the preferences of the CDU, from which it also could expect some sense of responsibility for the common enterprise in sustaining a workable pension system, instead of various and conflicting concerns of interest groups and single Länder governments.

The futile attempts to pursue the 'Grand Coalition strategy' can actually be seen as a sub-strategy of a broader, more diverse set of strategies, which has been called 'experimental law-making' (Lamping and Rüb 2002: 3). This style of law-making can be defined as 'a relatively unprepared and unplanned style' of decision-making which systematically involved 'situational and ad hoc consensus-building' (ibid.: 21). In the view of Lamping and Rüb, experimental law-making was not necessarily a sign of the weakness of the Schröder government, but a political strategy that was pursued deliberately 'to overcome the complex and long-enduring consensus-building processes within the German political system and its corporatist networks' (ibid.: 21). Experimental law-making can be seen as a political instrument used by the institutionally weak federal government in order to maximise its leverage. In contrast to the pure 'Grand Coalition strategy', experimental law-making makes use of different coalition partners depending on the situation at hand. The need for coalition building also varies with the different stages of the lawmaking process.

The Schröder government broke with traditions of policy-making by circumventing the tight-knit corporatist pension policy network, which consisted of representatives of the social partners, the social insurance associations as well as leading party experts and which had dominated pension politics in the 1990s (Lamping and Rüb 2002: 18-19). The Schröder government reduced the influence of the network by centralising decisionmaking power at the Chancellor's Office and by taking power away from the Ministry of Labour and Social Affairs (ibid.: 18). The strengthening of the second and third pillars of the pension system is also expected to lead to an opening of the policy networks towards new actors like private insurances and investment funds (ibid.: 22), which may sustainably change the nature of policy-making in pension politics.

Another example of experimental law-making is the involvement of the unions, which constitutes a move away from formal to informal veto points (in contrast to the Austrian case, where informal veto points were circumvented). When it became clear in the autumn of 2000 that the opposition was not willing to cooperate, Schröder tried to get the consent of the unions. This was not an easy task, because the unions had been mobilising against the government during the autumn. Schröder also lost some political capital by crying out 'Basta!' (which means: 'this is enough, no more!') on a union congress to defy rising demands by the unions (Die 
Welt, 9 November 2000). On further request of the unions, however, the government later introduced some provisions on occupational pensions that had not been part of the bill before. Because occupational pensions are somewhat privileged against private pensions, this may indeed lead to a major system transformation in the long run. For example, in contrast to individual investment instruments, occupational pension schemes do not have to be certified (Schmähl 2004: 184). And whereas the subsidies for the Riester-Rente are no longer adjusted after 2008, the subsidies for occupational pensions are adjusted dynamically (ibid.: 186). What is more, the employee has the right to convert up to 4 per cent of gross wages into occupational pension claims from 2002 onwards, which stands in contrast to the provisions of the Riester-Rente, where the subsidised share of wages only reaches 4 per cent in 2008. ${ }^{15}$ Apart from the possibility of earnings conversion, the 2001 reform also introduced a new type of occupational pension arrangement: the so-called Pensionsfund, which, in contrast to existing types of pension funds (the so-called Pensionskassen), is allowed to invest in a greater variety of assets (and is therefore expected to create higher revenues) (ibid.: 190). Another important element of the reform is the inclusion of occupational pension schemes in the collective arrangements (the Tarifverträge), which had been common in the public, but not in the private sector (ibid.: 158-59). Previously, occupational pensions had been granted individually and at the discretion of the employer. Now the unions have gained a major say in the configuration and implementation of occupational pension schemes.

Yet another example of the influence of the unions is the following story. Shortly before the final decision on the bill in the Bundestag, the head of the influential IG Metall union, Klaus Zwickel, called Schröder's office to point out that he had found a passage in the law that he could not accept. The provision in question was indeed very important, because it contained the obligation for the government to guarantee a certain level of pension benefits. Schröder was immediately contacted and himself talked with Riester and the head of the parliamentary faction, Peter Struck, to make sure that the union's request was fulfilled (Der Spiegel, 29 January 2001).

Why was the government so desperate to get the consent of the unions by making major concessions? Because attempts to engage the CDU had largely failed, Schröder was in need of another coalition partner. Although the unions did not have any formal veto power, their informal veto potential is considerable. It is hardly likely that Schröder would have been politically able to push the reform through parliament against the opposition, against the unions, and against public opinion. He needed at least one coalition partner to make the reform politically feasible. In an institutional environment with many veto players, the reform government has to forge broad coalitions; a unilateral strategy of pushing through with reforms is not possible. As previously argued, if there is no strong formal or 
informal coalition between the major parties that enables them to fight off interest groups jointly, the big mass parties (Volksparteien) are rather vulnerable towards requests from interest groups like unions or employers' organisations that have long-established personal links to the Volksparteien. The government was also willing to make concessions to the unions, because, for Schröder, the policy content was less important than the expected political gain of being able to claim the label of 'reform chancellor'. Pushing a major reform through the minefield of Germany's political institutions meant a major gain in political capital. Merkel's inability to prevent Schröder's tax reform in 2000 had already been a political victory for Schröder and a major defeat for Merkel. The pension reform was set to be the next victory.

However, to get the bill through the Bundesrat, the government had to engage in yet another exercise in ad-hoc coalition building. Before introducing the bill into parliament, the government had already split the reform bill into two parts, of which only one needed the consent of the Bundesrat. But the CDU insisted on renegotiating those parts of the reform contained in the bill that did not need the consent of the Bundesrat, so that in the end the whole reform was on the table again. After the consensus talks with the CDU failed in late March, the government changed strategies. By making specific concessions to individual Länder governments, the coalition was able to secure enough votes to pass the bill. This strategy of ad hoc coalition building had already been successfully used in the decision on tax reform in 2000. The government, for example, promised Berlin and Brandenburg to set up the federal agency that would take care of the certification of investment products in their territory, thereby creating about 1,000 badly needed new jobs. On the demand of Rhineland-Palatinate, in which the liberal FDP was in the government coalition, the government included the recognition of real estate as private savings in the bill. As became clear in the example of union involvement, the motley crew of Länder governments Schröder had to bring together has left its impact on the reform in the form of special interest policies.

To conclude, by engaging in experimental law-making the Schröder government was successfully able to incorporate informal veto players (like the unions) in the reform coalition and to prevent the attempts of the opposition to completely hijack the decision-making process. This heavy emphasis on the political aspects of the reform has had a major impact on the content of the reform, as made clear during the preceding discussion. The influence of the unions led to less than planned reductions in the benefit level and to the institutionalisation of privileges in the reformed system of occupational pensions, which will in the long run strengthen the position of the unions. The ad hoc coalition building in the Bundesrat and the accompanying piecemeal concessions to Länder governments hurt the clarity and credibility of the reform project. 


\section{Conclusions}

This case study has shown the importance of political institutions in general and veto points in particular in shaping the magnitude and the direction of policy change. The Austrian case demonstrates that the ability of the central government to pursue a strategy of 'pushing through' has made larger policy changes towards retrenchment possible and therefore the departure from the conservative welfare type unnecessary. This article has argued that the formal veto power of political actors in the 'grand coalition state' of Austria is far less than in the German case. When 'push comes to shove', the Austrian central government is better able to stand its ground, because fewer veto points enable opposing political actors to exercise effective veto power. In Germany, restricted powers have forced the government to engage in lengthy negotiations with diverse actors (the opposition parties, the unions, the Länder governments). The multiplicity of veto points impeded the pursuit of a homogenous, non-clientelistic policy strategy. But, and this is another major point, it encouraged the departure from inherited policy patterns. Rising problem pressure and a certain willingness of public opinion for major reform forced the government to produce some reform action. The multiplicity of veto players made plain retrenchment almost impossible, thereby encouraging the search for new policy strategy in an erroneous process of 'experimental law-making'. The result was system change, which is minor in the short term, but expected to become significant in the long run.

One possible challenge to our institutional argument hinges on the role of political parties and their policy preferences. One could argue that the Austrian Christian democrats just had different policy preferences than the German social democrats. The party difference thesis has made significant contributions to welfare state research (Schmidt 1996b). Yet, in this case, partisan differences do not matter much. First, both social and Christian democrats have played their part in the establishment of the welfare state, especially in Germany and Austria (Schmidt 1998; van Kersbergen 1995). Both party families are reluctant when it comes to social policy retrenchment. Second, the conservative welfare state type is confronted with similar challenges (Pierson 2001), thereby making country differences less important. Pressure increasingly restricts the space of policy options for political parties in government. Germany and Austria are both faced with similar challenges and similar inherited welfare state regimes, contributing to the comparability of the cases.

Our conclusions can be summarised as follows:

1. Not having to deal with powerful veto players is a major resource for a government that engages in unpopular welfare state reforms, which in times of austerity (Pierson 2001) will inevitably contain some elements of retrenchment. Multiple veto points in the political institutions of a 
country establish access points for partisan veto players and interest groups that will normally have an incentive to block retrenchment reforms, either because it is electorally popular to do so or because the reforms endanger their position as informal veto players (mainly in the case of unions). Because the Austrian government was relatively unconstrained by veto players and the main challenges to the reform came from within its own ranks, the magnitude of the policy change (measured as reductions in benefit level) is considerably greater than in Germany. However, the pressure to engage in innovative and systemtransforming policy initiatives was lower.

2. These findings stand in contrast to the predictions of Ebbinghaus and Hassel (2000) and Culpepper (2002), who think that a successful cooperation of the government with the social partners is a necessary condition for successful welfare state reform, either to eliminate their informal veto potential, to facilitate coordination between different policy areas (Ebbinghaus and Hassel 2000), or to provide the government with the necessary relational information to ensure the political feasibility of the reform (Culpepper 2002). The AustrianGerman comparison shows that a strategy of 'pushing through' can in the end lead to more substantial policy changes, whereas in Germany the magnitude of the reform was lowered by the involvement of the unions, who were opposed to deep cuts in the benefit level.

3. But a cooperative interaction orientation (Scharpf 2000a) is a reform asset, too. The Austrian example shows that the government did not want to abandon the system of consensual policy-making altogether, because it creates all the political benefits Ebbinghaus and Hassel (2000) and Culpepper (2002) speak about. A cooperative interaction orientation facilitates strategies of common problem-solving instead of competitive bargaining (Scharpf 2000a: 214-25). In the German case, the interaction orientation of the CDU was more competitive than cooperative, which made the success of negotiations very improbable.

4. Drawing all previous conclusions together in one thesis, this paper argues that participation of social partners is neither a necessary nor a sufficient condition for successful reform. In general, welfare state reforms seem to be more successful in an institutional setting where the non-existence of powerful (formal) veto players allows the government to push through with the unpopular but necessary retrenchment parts of the reform, whereas the overall success and sustainability of a reform will be secured by successful cooperation with social partners and other societal actors. If a government is heavily constrained by formal veto players and is not able to build up a credible 'shadow of hierarchy' (Scharpf 2000a: 323) by other means, the power of informal veto players increases and has an impact on the reform outcome. 


\section{Notes}

1. The certification is done by a federal agency. The criteria for obtaining a certificate are: guarantee of the nominal value of the payments made, the assets will be paid in monthly rates if the person has reached the age of 60 (no lump sum payments), cost transparency (Bundesregierung 2004; Schmähl 2004: 184).

2. In absolute terms, in 2008 , those who invest at least 4 per cent of their gross wages will receive up to $€ 150$ ( $€ 300$ for couples) as maximum allowance (plus a maximum of $€ 180$ per child per year). The total expected amount of subsidies and tax exemptions is $€ 11$ bn (Lamping and Rüb 2002: 9).

3. The standard pension is an abstract orientation device. It is the pension that the standard pensioner, who has worked and paid contributions for 45 years and had average earnings each year, will receive (Bundesregierung 2004).

4. Seeleib-Kaiser 2003, Schmähl 2004, Leibfried and Obinger 2004 speak of a reduction from 70 per cent to 64 per cent, while Kohl 2001, Lamping and Rüb 2002, and official documents (VDR 2001; Bundesregierung 2004) speak of a reduction from 70 per cent to 67 per cent.

5. This view stands in contrast to the explicit inclusion of a guarantee to maintain the 67 per cent level in the final bill.

6. Cf. http://www.sozialversicherung.at/esvapps/page/page.jsp?p_pageid $=110 \&$ p_menuid $=$ 7963\&p_id $=4$.

7. Cf. EIU Country Report Austria, May 2003: 20.

8. http://www.fpoe.at/.

9. The government's 2002 pension strategy mentions the expansion of the second and third pillars, but only as a minor point among others (Bundesregierung Österreich 2002: 6).

10. Cf. the website of the Bundesrat at http://www.parlament.gv.at.

11. Normally, bills emerge out of the government's bureaucracy and not from the parliamentary arena. The government is obliged in a formal process (the Begutachtungsverfahren) to listen to the statements of the social partners. This is the single most important formal veto position of the social partners, which is in fact not a strong position, because the government is not obliged to adopt the position of the social partners.

12. Lamping and Rüb 2002.

13. The Kohl government was confronted with a majority of SPD-governed Länder during most of the 1990s, whereas Schröder has lost this majority in 1999 and is now confronted with a much more coherent block of CDU-governed states.

14. The new party secretary general, Laurenz Meyer, for example, presented a very controversial election campaign advertisement showing Chancellor Schröder as a criminal. The crime he was accused of was the pension reform. This coup however created a huge political backlash and the CDU was forced to apologise to Schröder and withdraw the advertisement.

15. In addition to that, the ceiling up to which the subsidies can be claimed is much higher for earnings conversion than for the Riester-Rente and is also adjusted dynamically (Schmähl 2004: 187)

\section{References}

Bundesregierung Österreich (2002). Bericht über die österreichische Rentenstrategie 2002. Wien: Bundesregierung.

Bundesregierung (2003). Rentenversicherungsbericht 2003. Berlin: Bundesregierung.

Bundesregierung (2004). Renten-ABC, http://www.bundesregierung.de/artikel-,413.513725/ Renten-ABC.htm\#Nachhaltigkeitsfaktor.

Culpepper, Pepper (2002) "“ Powering, Puzzling and, Pacting”: The Informational Logic of Negotiated Reforms', Journal of European Public Policy, 9:5, 774-90. 
Czada, Roland (2003). 'Der Begriff der Verhandlungsdemokratie und die vergleichende PolicyForschung', in Renate Mayntz and Wolfgang Streeck (eds.), Die Reformierbarkeit der Demokratie: Innovationen und Blockaden, Festschrift für Fritz W. Scharpf. Frankfurt and New York: Campus, 173-204.

Ebbinghaus, Bernhard, and Anke Hassel (2000). 'Striking Deals: Concertation in the Reform of Continental European Welfare States', Journal of European Public Policy, 7:1, 44-62.

Esping-Andersen, Gøsta (1990). The Three Worlds of Welfare Capitalism. Cambridge: Polity Press.

Hemerijck, Anton, Brigitte Unger and Jelle Visser (2000). 'How Small Countries Negotiate Change: Twenty-Five Years of Policy Adjustment in Austria, the Netherlands, and Belgium', in Fritz W. Scharpf and Vivien A. Schmidt (eds.), Welfare and Work in the Open Economy: Volume II. Diverse Responses to Common Challenges. Oxford: Oxford University Press, 175263.

Immergut, Ellen (1992). The Political Construction of Interests: National Health Insurance Politics in Switzerland, France, and Sweden, 1930-1970. New York: Cambridge University Press.

Kitschelt, Herbert (2001). 'Partisan Competition and Welfare State Retrenchment: When Do Politicians Choose Unpopular Policies?', in Paul Pierson (ed.), The New Politics of the Welfare State. Oxford and New York: Oxford University Press, 265-302.

Kohl, Jürgen (2001). 'Die deutsche Rentenversicherung im europäischen Kontext', Zeitschrift für Sozialreform, 47, 619-43.

Lamping, Wolfram, and Friedbert W. Rüb (2002). 'From the Conservative Welfare State to "Something Uncertain Else": The New German Pension Politics'. Diskussionpapier Nr. 12, Abteilung Sozialpolitik und Public Policy, Universität Hannover.

Leibfried, Stephan, and Herbert Obinger (2004). 'The State of the Welfare State: German Social Policy between Macroeconomic Retrenchment and Microeconomic Recalibration', in Herbert Kitschelt and Wolfgang Streeck (eds.), Germany: Beyond the Stable State. London and Portland, OR: Frank Cass, 199-218.

Müller, Wolfgang C. (2003) 'Austria: Imperfect Parliamentarism but Fully-fledged Party Democracy', in Kaare Strøm, Wolfgang C. Müller and Torbjörn Bergman (eds.), Delegation and Accountability in Parliamentary Democracies. Oxford: Oxford University Press, 221-52.

Obinger, Herbert (2001). 'Vetospieler und Staatstätigkeit in Österreich: Sozial- und wirtschaftspolitische Reformchancen für die neue ÖVP/FPÖ-Regierung', Zeitschrift für Parlamentsfragen, 2, 360-86.

OECD (2002). Economic Surveys: Germany. Paris: OECD.

OECD (2003). Economic Surveys: Austria. Paris: OECD.

Pierson, Paul (2001). 'Coping with Permanent Austerity: Welfare State Restructuring in Affluent Democracies', in Paul Pierson (ed.), The New Politics of the Welfare State. Oxford: Oxford University Press.

Scharpf, Fritz W. (1985). 'Die Politikverflechtungs-Falle: Europäische Integration und deutscher Föderalismus im Vergleich', Politische Vierteljahresschrift, 26:4, 323-56.

Scharpf, Fritz, W. (2000a). Interaktionsformen: Akteurzentrierter Institutionalismus in der Politikforschung. Opladen: Leske + Budrich.

Scharpf, Fritz W. (2000b). 'Vulnerabilities and Capabilities', in Fritz W. Scharpf and Vivien A. Schmidt, (eds.), Welfare and Work in the Open Economy, Volume I. Oxford: Oxford University Press, 21-124.

Schmähl, Winfried (2003). 'Private Pensions as Partial Substitute for Public Pensions in Germany', in Gordon L. Clark and Noel Whiteside (eds.), Pension Security in the 21st Century: Redrawing the Public-Private Debate. Oxford: Oxford University Press, 115-43.

Schmähl, Winfried (2004). 'Paradigm Shift in German Pension Policy: Measures Aiming at a New Public-Private Mix and their Effects', in Martin Rein and Winfried Schmähl (eds.), Rethinking the Welfare State: The Political Economy of Pension Reform. Cheltenham, UK and Northampton, MA: Edward Elgar, 153-204. 
Schmidt, Manfred G. (1996a). 'Germany: The Grand Coalition State', in Josep M. Colomer (ed.), Political Institutions in Europe. London and New York: Routledge, 62-98.

Schmidt, Manfred G. (1996b). When Parties Matter: A Review of the Possibilities and Limits of Partisan Influence on Public Policy', European Journal of Political Research, 30, 155-83.

Schmidt, Manfred G. (1998). Sozialpolitik in Deutschland: Historische Entwicklung und internationaler Vergleich, 2nd edn. Opladen: Leske + Budrich.

Schmidt, Manfred G. (2000). Demokratietheorien, 3. Auflage. Opladen: Leske + Budrich.

Schmidt, Manfred G. (2002). 'Politiksteuerung in der Bundesrepublik Deutschland', in Frank Nullmeier and Thomas Saretzki (eds.), Jenseits des Regierungsalltags: Strategiefähigkeit politischer Parteien. Frankfurt a.M. and New York: Campus, 23-38.

Seeleib-Kaiser, Martin (2003). 'Continunity or Change? Red-Green Social Policy after 16 Years of Christian-Democratic Rule'. ZES-Arbeitspapier 3/2003.

Tálos, Emmerich (2002). 'Soziale Sicherung in Österreich: Zwischen Kontinuität und Neujustierung?'. ZES-Arbeitspapier 7/2002.

Tálos, Emmerich (2004). 'Umbau des Sozialstaates? Österreich und Deutschland im Vergleich', Politische Vierteljahresschrift, 45:2, 213-36.

Tsebelis, George (2002). Veto Players: How Political Institutions Work. Princeton, NJ: Princeton University Press.

Van Kersbergen, Kees (1995). Social Capitalism: A Study of Christian Democracy and the Welfare State. London and New York: Routledge.

VDR (2001). Rentenreform 2001: Das Wichtigste im Überblick. Frankfurt a.M.: VDR. 